\title{
Comparative study of low dose of capecitabine versus standard dose in metastatic breast cancer: Efficacy and safety
}

Engy $M$ Aboelnaga $M D^{1 *}$, Wafaa El-beshbishi $\mathrm{MD}^{1}$

${ }^{1}$ Clinical Oncology and Nuclear Medicine Department,

Faculty of Medicine, Mansoura University, Egypt

Received 5 July 2019; Accepted 5 November 2019

\begin{abstract}
Background: A lower dose of capecitabine revealed better toxicity profiles and comparable efficacy in treatment of metastatic breast cancer (MBC). We aimed to evaluate the efficacy and toxicity of lower dose of capecitabine in comparison with the standard dose. Patients and methods: Patients were enrolled in two groups. Group 1 included 21 patients who received the standard dose of capecitabine (1250 mg/m² twice daily [BID] for 14 days), while the patients in group 2 (19 patients) received lower dose of capecitabine ( $850 \mathrm{mg} / \mathrm{m}^{2}$ BID for 14 days) every 3 weeks.

Results: In group 1, dose reduction was reported in 12 (57.1\%) patients versus 1 patient in group 2 (5.3\%; $P=0.0005)$. Patients in group 1 reported higher toxicity rates without any significant difference between the groups. The median duration of response was 17 weeks in group 1, while it was 19 weeks in group 2. Disease progression was recorded in 10 (47.6\%) patients in group 1 versus 8 (42.1\%) patients in group $2(P=0.81)$. The mean time to progression was $8.16 \pm 0.63$ months and the median was 10.1 months in group 1 , while the mean was $8.98 \pm 0.75$ months and the median was 10 months in group $2(P=0.66)$. The overall survival had a mean of $11.94 \pm 0.754$ and $11.24 \pm 0.665$ months, while the median was 13.1 and 13 months in groups 1 and 2 , respectively $(P=$ 0.9).

Conclusions: A lower dose of capecitabine provides MBC patients with an active therapy that can be continued for prolonged periods to achieve long-term disease control without compromising its antitumor activity.
\end{abstract}

Keywords: Capecitabine • Metastatic breast cancer • Low dose • Standard dose • Efficacy • Safety

\section{Introduction}

Capecitabine is an oral prodrug of fluoropyrimidine carbamate $^{[1]}$. It has shown relatively selective cytotoxicity against many tumor types when used as monotherapy or in combination with other agents. Administration of capecitabine as monotherapy has considerable activity in breast cancer patients previously treated with anthracyclines and/or taxanes, with response rates of about $15 \%-29 \%$. The US Food and Drug Administration (FDA) approved capecitabine for treatment of metastatic pretreated breast cancer with the dose recommended being $1250 \mathrm{mg} / \mathrm{m}^{2}$ twice daily (bid) for 14 days every 3 weeks $^{[2-4]}$.
The reported side effects with capecitabine treatment are palmar-plantar erythrodysesthesia (PPE or handfoot syndrome), diarrhea, and stomatitis ${ }^{[5,6]}$. In certain conditions, discontinuation of capecitabine treatment has been required in up to $17 \%$ of patients in clinical trials ${ }^{[7]}$. Based on data from a retrospective analysis which reported that dose adjustment of capecitabine did not have a negative impact on its efficacy ${ }^{[8,9]}$. Administration of lower dose of capecitabine was also studied in a prospective study using different dose schedules. A dose of $1000 \mathrm{mg} / \mathrm{m}^{2}$ administered bid for 14 days in a 3-week cycle or $825 \mathrm{mg} / \mathrm{m}^{2}$ on days 1-21 of a 28-day cycle led to achievement of better toxicity profile and 
comparable efficacy ${ }^{[10]}$. Lower fixed dose of capecitabine given as $1000 \mathrm{mg}$ bid for 14 days every 21 days was retrospectively analyzed in comparison to the standard dose; both doses yielded a comparable response rate (24.3\% vs $24 \%$, 95\% confidence interval [Cl]: 5.5-8.5, respectively) and median time to progression (TTP; 7 vs 5.1 months, $95 \% \mathrm{Cl}$ : 4.5-5.7, respectively) ${ }^{[11]}$.

In this prospective study, we aimed to evaluate the efficacy and toxicity of lower dose of capecitabine in metastatic breast cancer (MBC) patients compared with a control group that received the standard dose of capecitabine.

\section{Patients and methods}

Patients diagnosed with $\mathrm{MBC}$ were included in this prospective study that was conducted in Mansoura University Hospital and Meet Ghmer Oncology Center from January 2016 to December 2017. Patients were enrolled in two groups: group 1 (control group) included 21 patients who received the standard dose of capecitabine $\left(1250 \mathrm{mg} / \mathrm{m}^{2}\right.$ BID for 14 days followed by 1 week rest) and group 2 (patients group) included 19 patients who received a lower dose of capecitabine (850 $\mathrm{mg} / \mathrm{m}^{2}$ BID for 14 days every 3 weeks).

\subsection{Inclusion and exclusion criteria}

Inclusion criteria: Patients aged from 18 to 70 years with a confirmed diagnosis of breast cancer and metastatic disease (either visceral or bone metastasis) that was untreated or previously treated with hormonal therapy or chemotherapy (with any regimen, even if it contained 5-fluorouracil (5-FU), provided that it was administered at least 6 months before enrollment in the study) were included in the study. However, a minimum of about 3 weeks between the last treatment and the starting of treatment with capecitabine was required. Other criteria included Eastern Cooperative Oncology Group (ECOG) performance status (PS) $0-2$, adequate hematological function (absolute neutrophil count of $\geqslant 1.5 \times 10^{9} / \mathrm{L}$, WBC count $\geqslant 3.5 \times 10^{9} / \mathrm{L}$, hemoglobin $\geqslant 10 \mathrm{~g} / \mathrm{dL}$, and platelets $\geqslant 100 \times 10^{9} / \mathrm{L}$ ), and satisfactory baseline renal and liver functions.

Exclusion criteria: Patients with gastrointestinal diseases or malabsorption syndromes affecting the absorption of oral capecitabine, metabolic disease impairing the metabolism of capecitabine, clinically significant cardiac disease, and who have undergone active treatment with chemotherapy, radiotherapy, or hormonal treatment in previous 3 weeks were excluded.
Patients with history of previous secondary malignancy, significant medical problem, pregnancy or lactation, and male sex were also excluded from the study. Approvals of institutional review board and ethical committee were obtained, and the informed consent was signed by all patients before starting any active treatment.

\subsection{Pretreatment evaluation}

Before starting treatment, our cases were evaluated using complete clinical history, physical examination, laboratory evaluations, ECG, and baseline radiological evaluations for adequate tumor assessment.

\subsection{Assessment of response and toxicities}

Capecitabine regimen was administered every 3 weeks and continued till unacceptable toxicity or disease progression. Blood chemistry and toxicity measurements were performed every 3 weeks. Toxicities were graded using toxicity grading of the common terminology criteria for adverse events ( $\mathrm{NCl}-$ CTC, version 4.0) and applied to patients who received at least one cycle of capecitabine. Dose modification or delay of treatment was applied to patients experiencing grade 2 or more toxicity. Non-compliant patients for more than 1 week were withdrawn from the study. Response to chemotherapy was assessed after three cycles based on Response Evaluation Criteria in Solid Tumors (RECIST) criteria. Overall clinical response rate included achievement of complete response (CR) and partial response (PR). Progression of disease (PD) was considered if the tumor dimensions increased by $20 \%$ or a new lesion developed.

\subsection{Primary and secondary endpoints}

The primary endpoint of the study was the overall response rate. The secondary endpoints were toxicity assessment, TTP, and overall survival (OS).

\subsection{Statistical analysis}

Statistical Package for Social Sciences (SPSS) software (version 22.0, USA) was used for statistical analysis. Quantitative data were presented as median or mean \pm standard deviation (SD). Fisher's exact test was used for qualitative data. Chi-square test was used to test the statistical significance. Overall response rate included 
cases with $\mathrm{CR}$ and PR. Duration of response was determined from the time of documentation of response till disease progression. The Kaplan-Meier method was used for survival data. TTP was the time from the date of initiation of capecitabine to the date of evidence of disease progression or death in the absence of disease progression. The OS was determined from the start of treatment to the time of the last follow-up visit or death whatever the cause may be. Logrank was used for comparison of curves. The $95 \% \mathrm{Cls}$ were calculated with the exact method. All $P$ values were two-tailed, and a $P$ value of $<0.05$ was considered significant.

\section{Results}

This study recruited 40 patients with $\mathrm{MBC}$ who were divided into two groups: group 1 included 21 patients receiving standard dose of capecitabine and group 2 included 19 patients receiving low dose of the same drug. The median age of the first group was 49 years (range: 40-59 years) and the second group was 50 years (range: 38-64 years) with no statistically significant difference between them. Patients older than 45 years were detected in $81 \%$ and $78.9 \%$ of cases in groups 1 and 2 , respectively $(P=0.51)$. Premenopausal patients numbered $11(52.4 \%)$ and $8(42.1 \%)$ cases in groups 1 and 2 , respectively $(P=0.97)$. Bone metastasis was the most common site of metastasis in both groups (14 [66.7\%] vs 13 [68.4\%] patients in groups 1 and 2, respectively). Triple-negative cases were comparable between both groups $(23.8 \%$ in group 1 and $21.1 \%$ in group 2). The characteristics of all patients are described in Table 1, with no significant difference noted between both groups.

Adjuvant or neoadjuvant chemotherapy was administered to 18 patients (85.7\%) and 17 patients $(89.5 \%)$ in groups 1 and 2, respectively. Most of the patients received sequential anthracycline/taxanes in both groups, as presented in Table 2. Regarding palliative chemotherapy used before capecitabine administration, taxane with or without carboplatin was given to two patients in group 1 and three patients in group 2, while navelbine \pm 5 -FU and gemcitabine-cisplatin/carboplatin were given to two and three patients versus four and two patients in groups 1 and 2, respectively. 5-FU was administered to seven and nine patients in cohorts 1 and 2, respectively (i.e. given to five patients as an adjuvant and two patients as a palliative treatment in group 1 versus six patients as an adjuvant and three patients as a palliative treatment in group 2).

Capecitabine was used as the first-line treatment in most of the patients $(66.7 \%$ in group 1 vs $47.4 \%$ in group 2), with no statistically significant difference found between them. The median number of cycles was six cycles in group 1 and eight cycles in group $2(P=$ $0.76)$. There was a statistically significant difference $(P$ $=0.0005)$ in dose reduction of capecitabine regimen between the two groups. In group 1, dose reduction was reported in $12(57.1 \%)$ patients and ranged between $25 \%$ and $50 \%$ because of the reported toxicities and associated comorbidities, while there was only 1 patient $(5.3 \%)$ in group 2 experiencing dose reduction (25\%). However, dose modification was needed after a median of two cycles (range: one to five cycles). In addition, cycle delay was recorded in 11 (52.3\%) and $4(21.1 \%)$ patients in groups 1 and 2 , respectively, with a statistically significant difference $(P=0.041)$ found between the groups. The cycle was delayed in six and three patients for 1 week and in two and one patient for 2 weeks in groups 1 and 2, respectively. A delay for 3 weeks was recorded for only two patients in group 1. Moreover, two patients discontinued the treatment in cohort 1 versus one case in cohort 2 due to intolerance to capecitabine because of fatigue and gastrointestinal toxicities (Table 2).

Table 3 shows the common toxicities reported in the study. The most common toxicity was HFS, which was documented in 13 patients $(61.9 \%)$ in the standard dose cohort versus 9 patients $(47.3 \%)$ in the low-dose cohort ( 4 and 2 patients vs 2 and no patients showed grade 2 and 3 toxicity in groups 1 and 2, respectively). However, a lower incidence of grade 2 and 3 was detected in group 2 and the difference was statistically insignificant. The next frequent toxicity was fatigue, which was recorded as grade 2 and 3 in three and one patient in group 1 versus two and no patient in group 2, with no statistically significant difference found between the groups. Concerning gastrointestinal toxicities, diarrhea was the most frequent manifestation and grade 3 was reported only in group 1 in a total of three patients $(14.2 \%)$. Patients who received the standard dose showed a higher incidence of hematological toxicities, mainly in grade 3, compared with those treated with the low dose; however, the difference did not reach statistically significant level. It is worth mentioning that grade 4 toxicity was not detected in our patients.

All 40 patients were assessed for the drug efficacy after a median follow-up of 8 months (range: 5-14 months). The data of response and survival rates are shown in Table 4. In regard to the response rate, CR was achieved in one patient in group 1 versus two patients in group 2. Patients who experienced overall clinical response $(C R+P R)$ numbered eight $(38 \%)$ versus seven $(36.8 \%)$ patients in groups 1 and 2, respectively. The median duration of response was 17 weeks (range: 
Table 1: Patients and tumor characteristics.

\begin{tabular}{|c|c|c|c|}
\hline Items & Standard dose & Low dose & $P$ value \\
\hline $\begin{array}{l}\text { Age (years) } \\
\text { Range } \\
\text { Mean } \pm \text { SD } \\
\text { Median }\end{array}$ & $\begin{array}{l}40-59 \\
49.5 \pm 4.9 \\
49\end{array}$ & $\begin{array}{l}38-64 \\
50.6 \pm 7.2 \\
50\end{array}$ & 0.87 \\
\hline $\begin{array}{l}\text { Age groups } \\
\leq 45 \text { years } \\
>45 \text { years }\end{array}$ & $\begin{array}{l}4(19 \%) \\
17(81 \%)\end{array}$ & $\begin{array}{l}4(21.1 \%) \\
15(78.9 \%)\end{array}$ & 0.516 \\
\hline $\begin{array}{l}\text { Menopausal state } \\
\text { Premenopausal } \\
\text { Postmenopausal }\end{array}$ & $\begin{array}{l}11(52.4 \%) \\
10(47.6 \%)\end{array}$ & $\begin{array}{l}8(42.1 \%) \\
11(57.9 \%)\end{array}$ & 0.971 \\
\hline $\begin{array}{l}P S \\
0 \\
1 \\
2\end{array}$ & \begin{tabular}{|l}
$5(23.8 \%)$ \\
$11(52.4 \%)$ \\
$5(23.8 \%)$
\end{tabular} & $\begin{array}{l}4(21.1) \\
10(52.6 \%) \\
5(26.3 \%)\end{array}$ & 0.507 \\
\hline $\begin{array}{l}\text { Surface area } \\
\text { Mean } \pm \text { SD } \\
\text { Site of metastasis } \\
\text { Bone } \\
\text { Lung } \\
\text { Liver } \\
\text { Brain } \\
\text { LNs }\end{array}$ & $\begin{array}{l}1.824 \pm 0.18 \\
\\
14(66.7 \%) \\
7(33.3 \%) \\
11(52.4 \%) \\
6(28.6 \%) \\
2(9.5 \%)\end{array}$ & $\begin{array}{l}1.795 \pm 0.16 \\
13(68.4 \%) \\
7(36.8 \%) \\
9(47.4 \%) \\
5(26.3 \%) \\
1(5.3 \%)\end{array}$ & $\begin{array}{l}0.86 \\
\\
0.906 \\
0.816 \\
0.752 \\
0.873 \\
0.935\end{array}$ \\
\hline $\begin{array}{l}\text { No. of involved site } \\
\quad 2^{1} \\
>\text { or }=3^{2}\end{array}$ & $\begin{array}{l}6(28.6 \%) \\
8(38.1 \%) \\
7(33.3 \%)\end{array}$ & $\begin{array}{l}7(36.8 \%) \\
6(31.6 \%) \\
6(31.6 \%)\end{array}$ & 0.84 \\
\hline $\begin{array}{l}\text { Hormonal state/Her } 2 \text { status } \\
\text { ER positive } \\
\text { PR positive } \\
\text { Her } 2 \text { positive } \\
\text { Triple negative }\end{array}$ & $\begin{array}{l}13(61.9 \%) \\
12(57.1 \%) \\
4(19 \%) \\
5(23.8 \%)\end{array}$ & $\begin{array}{l}12(63.2 \%) \\
8(42.1 \%) \\
5(26.3 \%) \\
4(21.1 \%)\end{array}$ & $\begin{array}{l}0.342 \\
0.302 \\
0.58 \\
0.83\end{array}$ \\
\hline- & & & \\
\hline $\begin{array}{l}\text { Initial stage } \\
\cdot \quad \text { Tumor stage }\end{array}$ & & & \\
\hline $\begin{array}{l}2 \\
3 \\
4 \\
-\quad \text { Lymph node stage }\end{array}$ & $\begin{array}{l}8(38.1 \%) \\
11(52.4 \%) \\
2(9.5 \%)\end{array}$ & $\begin{array}{l}10(52.6 \%) \\
9(47.4 \%) \\
0(0 \%)\end{array}$ & 0.312 \\
\hline $\begin{array}{l}0 \\
1 \\
2 \\
3\end{array}$ & $\begin{array}{l}3(14.3 \%) \\
7(33.3 \%) \\
7(33.3 \%) \\
4(19 \%)\end{array}$ & $\begin{array}{l}4(21.1 \%) \\
6(31.6 \%) \\
6(31.6 \%) \\
3(15.8 \%)\end{array}$ & 0.952 \\
\hline $\begin{array}{l}\text { - } \quad \text { Grade } \\
1 \\
2 \\
3\end{array}$ & $\begin{array}{l}2(9.5 \%) \\
11(52.4 \%) \\
8(38.1 \%)\end{array}$ & $\begin{array}{l}1(5.3 \%) \\
12(63.2 \%) \\
6(31.6 \%)\end{array}$ & 0.754 \\
\hline $\begin{array}{ll}\text { - } & \text { Type } \\
\text { Infiltrating duct carcinoma } \\
\text { Infiltrating lobular carcinoma }\end{array}$ & $\begin{array}{l}17(81 \%) \\
4(19 \%)\end{array}$ & $\begin{array}{l}17(89.5 \%) \\
2(10.5 \%)\end{array}$ & 0.664 \\
\hline
\end{tabular}


Table 2: Treatment characteristics.

\begin{tabular}{|c|c|c|c|}
\hline Items & Standard dose No. (\%) & Low dose No. (\%) & $P$ value \\
\hline $\begin{array}{l}\text { Prior adjuvant/NA CTH } \\
\text { No } \\
\text { Anthracycline/taxanes } \\
\text { Anthracycline }+5 \text {-FU }\end{array}$ & $\begin{array}{c}3(14.3 \%) \\
13(61.9 \%) \\
5(23.8 \%)\end{array}$ & $\begin{array}{l}2(10.5 \%) \\
11(57.9 \%) \\
6(31.6 \%)\end{array}$ & 0.899 \\
\hline $\begin{array}{l}\text { Adjuvant HT } \\
\text { - } \quad \text { Palliative CTH before capecitabine }\end{array}$ & 14 (66.7\%) & 11 (57.9\%) & 0.567 \\
\hline $\begin{array}{l}\text { Taxanes } \pm \text { carboplatin } \\
\text { Navelbine } \pm \text { FU } \\
\text { Gem-cisplatin/carboplatin } \\
\text { Others }\end{array}$ & $\begin{array}{c}2(9.5 \%) \\
2(9.5 \%) \\
3(14.3 \%)\end{array}$ & $\begin{array}{l}3(15.8 \%) \\
4(21.1 \%) \\
2(10.5 \%)\end{array}$ & 0.587 \\
\hline - $\quad$ Palliative HT & $11(52.4 \%)$ & $10(52.6 \%)$ & 0.987 \\
\hline $\begin{array}{l}\text { Use of capecitabine } \\
\text { First } \\
\text { Second } \\
\text { Third or more }\end{array}$ & $\begin{array}{l}14(66.7 \%) \\
5(23.8 \%) \\
2(9.5 \%)\end{array}$ & $\begin{array}{l}9(47.4 \%) \\
6(31.6 \%) \\
4(21.1 \%)\end{array}$ & 0.417 \\
\hline $\begin{array}{l}\text { Median no. of cycles (range) } \\
\text { Dose reduction } \\
\text { Cycle delay }\end{array}$ & $\begin{array}{c}6(2-8) \\
12(57.1 \%) \\
11(52.3 \%)\end{array}$ & $4(21.1 \%)$ & $\begin{array}{l}0.762 \\
<0.0005 \\
0.041\end{array}$ \\
\hline
\end{tabular}

CTH: chemotherapy; FU: fluorouracil; HT: hormonal treatment; NA: neoadjuvant.

Table 3: Treatment toxicities.

\begin{tabular}{|c|c|c|c|c|c|c|c|c|c|c|}
\hline \multirow{2}{*}{\multicolumn{2}{|c|}{ Items }} & \multicolumn{4}{|c|}{ Standard dose no. (\%) } & \multicolumn{4}{|c|}{ Low dose no. (\%) } & \multirow[t]{2}{*}{$P$ value } \\
\hline & & All & G1 & G 2 & G3 & All & G1 & G2 & G 3 & \\
\hline - & HFS & $13(61.9)$ & 7 (33.3) & $4(19)$ & $2(9.5)$ & $9(47.3)$ & $7(36.8)$ & $2(10.5)$ & 0 & 0.42 \\
\hline- & Fatigue & $12(57.1)$ & $8(38)$ & $3(14.2)$ & $1(4.7)$ & $8(42.1)$ & $6(31.5)$ & $2(10.5)$ & 0 & 0.66 \\
\hline- & Nausea & 7 (33.3) & $5(23.8)$ & $1(4.7)$ & $1(4.7)$ & $4(21)$ & $4(21)$ & 0 & 0 & 0.94 \\
\hline- & Vomiting & 7 (33.3) & 4 (19) & $3(14.2)$ & 0 & $4(21)$ & $2(10.5)$ & $2(10.5)$ & 0 & 0.93 \\
\hline- & Diarrhea & $9(42.8)$ & $4(19)$ & $2(9.5)$ & $3(14.2)$ & $6(31.5)$ & $5(26.3)$ & $1(5.2)$ & 0 & 0.58 \\
\hline- & Stomatitis & $7(33.3)$ & $3(14.2)$ & $3(14.2)$ & $1(4.7)$ & $4(21)$ & $3(15.7)$ & $1(5.2)$ & 0 & 0.33 \\
\hline \multirow[t]{4}{*}{-} & Hematological & & & & & & & & & \\
\hline & Anemia & $10(47.6)$ & $6(28.5)$ & $3(14.2)$ & $1(4.7)$ & $4(21)$ & $4(21)$ & 0 & 0 & 0.17 \\
\hline & Neutropenia & $8(38)$ & $3(14.2)$ & $4(19)$ & $1(4.7)$ & $4(21)$ & $3(15.7)$ & $1(5.2)$ & 0 & 0.41 \\
\hline & Thrombocytopenia & 7 (33.3) & $4(19)$ & $3(14.2)$ & 0 & $2(10.5)$ & $2(10.5)$ & 0 & 0 & 0.14 \\
\hline
\end{tabular}

HFS: Hand and foot syndrome

Table 4: Response data.

\begin{tabular}{|c|c|c|c|}
\hline Items & Standard dose & Low dose & $P$ value \\
\hline $\begin{array}{ll} & \text { Complete response } \\
- & \text { Overall clinical response (CR+ PR) } \\
- & \text { Stable disease } \\
- & \text { Progressive disease }\end{array}$ & $\begin{array}{c}1(4.7) \\
8(38) \\
3(14.2) \\
10(47.6)\end{array}$ & $\begin{array}{l}2(10.5) \\
7(36.8) \\
4(21) \\
8(42.1)\end{array}$ & 0.81 \\
\hline $\begin{array}{ll}- & \text { Mean TTP } \\
- & \text { Median TTP } \\
- & \text { Mean OS } \\
-\quad & \text { Median OS }\end{array}$ & $\begin{array}{c}8.16 \pm 0.63 \\
10.1 \\
11.94 \pm 0.754 \\
13.1\end{array}$ & $\begin{array}{c}8.98 \pm 0.75 \\
10 \\
11.24 \pm 0.665 \\
13\end{array}$ & $\begin{array}{l}0.66 \\
0.9\end{array}$ \\
\hline
\end{tabular}

CR: complete response; OS: overall survival; PR: partial response; TTP: time to progression. 
Table 5: Relations of response data.

\begin{tabular}{|c|c|c|c|c|c|c|c|c|c|}
\hline \multirow{2}{*}{$\begin{array}{l}\text { Prognostic } \\
\text { factors }\end{array}$} & \multicolumn{2}{|c|}{ All patients (40) } & \multirow{2}{*}{$\begin{array}{c}P \\
\text { value }\end{array}$} & \multicolumn{2}{|c|}{$\begin{array}{l}\text { Standard dose } \\
\text { (group } 1=21 \text { ) }\end{array}$} & \multirow{2}{*}{$\begin{array}{c}P \\
\text { value }\end{array}$} & \multicolumn{2}{|c|}{$\begin{array}{c}\text { Low dose } \\
\text { (group } 2=19 \text { ) }\end{array}$} & \multirow[b]{2}{*}{$P$ value } \\
\hline & $\begin{array}{c}\text { Response } \\
\text { no. (\%) }\end{array}$ & $\begin{array}{c}\text { No } \\
\text { response } \\
\text { no. (\%) }\end{array}$ & & $\begin{array}{c}\text { Response } \\
\text { no. (\%) }\end{array}$ & $\begin{array}{c}\text { No } \\
\text { response } \\
\text { no. (\%) } \\
\end{array}$ & & $\begin{array}{c}\text { Response } \\
\text { no. (\%) }\end{array}$ & $\begin{array}{c}\text { No } \\
\text { response } \\
\text { no. (\%) } \\
\end{array}$ & \\
\hline $\begin{array}{l}\text { Age group } \\
\leq 45 \text { years } \\
>45 \text { years }\end{array}$ & $\begin{array}{l}7(17.5) \\
1(2.5)\end{array}$ & $\begin{array}{c}8(20) \\
24(60)\end{array}$ & 0.001 & $\begin{array}{c}4(19) \\
0\end{array}$ & $\begin{array}{c}4(19) \\
13(61.9)\end{array}$ & 0.005 & $\begin{array}{c}3(15.7) \\
1(5.2)\end{array}$ & $\begin{array}{c}4(21) \\
11(57.8)\end{array}$ & 0.075 \\
\hline $\begin{array}{l}\text { Menopausal state } \\
\text { Premenopausal } \\
\text { Postmenopausal }\end{array}$ & $\begin{array}{l}7(17.5) \\
12(30)\end{array}$ & $\begin{array}{c}8(20) \\
13(32.5)\end{array}$ & 0.93 & $\begin{array}{c}4(19) \\
7(33.3)\end{array}$ & $\begin{array}{c}4(19) \\
6(28.5)\end{array}$ & 0.84 & $\begin{array}{l}3(15.7) \\
5(26.3)\end{array}$ & $\begin{array}{c}4(21) \\
7(36.8)\end{array}$ & 0.96 \\
\hline $\begin{array}{l}\text { Grade } \\
1 \\
2 \\
3\end{array}$ & $\begin{array}{l}3(7.5) \\
5(12.5) \\
7(17.5)\end{array}$ & $\begin{array}{c}0 \\
18(45) \\
7(17.5)\end{array}$ & 0.015 & $\begin{array}{l}2(9.5) \\
2(9.5) \\
4(19)\end{array}$ & $\begin{array}{c}0 \\
9(42.8) \\
4(19)\end{array}$ & 0.61 & $\begin{array}{c}1(5.2) \\
3(15.7) \\
3(15.7)\end{array}$ & $\begin{array}{c}0 \\
9(47.3) \\
3(15.7)\end{array}$ & 0.23 \\
\hline $\begin{array}{l}\text { Triple negative } \\
\text { No } \\
\text { Yes }\end{array}$ & $\begin{array}{l}14(35) \\
1(2.5)\end{array}$ & $\begin{array}{l}17(42.5) \\
8(20)\end{array}$ & 0.063 & $\begin{array}{c}8(38) \\
0\end{array}$ & $\begin{array}{c}8(38) \\
5(23.8)\end{array}$ & 0.044 & $\begin{array}{l}6(31.5) \\
3(15.7)\end{array}$ & $\begin{array}{c}9(47.3) \\
1(5.2)\end{array}$ & 0.85 \\
\hline $\begin{array}{l}\text { No. of metastatic } \\
\text { sites } \\
1 \\
2 \\
\geq 3\end{array}$ & $\begin{array}{l}10(25) \\
4(10) \\
1(2.5)\end{array}$ & $\begin{array}{l}3(7.5) \\
10(25) \\
12(30)\end{array}$ & 0.01 & $\begin{array}{c}4(19) \\
3(14.2) \\
1(4.7)\end{array}$ & $\begin{array}{c}1(4.7) \\
5(23.8) \\
7(33.3)\end{array}$ & 0.051 & $\begin{array}{c}6(31.5) \\
1(5.2) \\
0\end{array}$ & $\begin{array}{l}2(10.5) \\
5(26.3) \\
5(26.3)\end{array}$ & 0.011 \\
\hline $\begin{array}{l}\text { Treatment line } \\
\text { First } \\
\text { Second } \\
\text { Third or more }\end{array}$ & $\begin{array}{c}14(35) \\
1(2.5) \\
0\end{array}$ & $\begin{array}{l}11(27.5) \\
9(22.5) \\
5(12.5)\end{array}$ & .007 & $\begin{array}{c}7(33.3) \\
1(4.7) \\
0\end{array}$ & $\begin{array}{l}6(28.5) \\
5(23.8) \\
2(9.5)\end{array}$ & 0.15 & $\begin{array}{c}7(36.8) \\
0 \\
0\end{array}$ & $\begin{array}{c}5(26.3) \\
4(21) \\
3(15.7)\end{array}$ & 0.039 \\
\hline
\end{tabular}

11-22 weeks) in group 1, while it was 19 weeks (range: 10-25 weeks) in group 2. Three patients revealed disease stabilization (stable disease [SD]) in cohort 1 (median $=25$ weeks) and four patients showed SD in cohort 2 (median = 28 weeks). Disease progression was recorded in $10(47.6 \%)$ patients in group 1 versus $8(42.1 \%)$ patients in group 2, but the difference was statistically insignificant $(P=0.81)$. After disease progression, two patients received best supportive care, three patients received weekly paclitaxel \pm carboplatin, while gemcitabine-cisplatin/carboplatin and navelbine were administrated to three and two patients, respectively. In the second group, one, four, two, and one patient received supportive care, weekly paclitaxel \pm carboplatin, gemcitabine-cisplatin/carboplatin, and navelbine, respectively.

The overall clinical response in all patients had a statistically significant relation to the age group, grade, number of metastatic sites, and the line of treatment ( $P=0.001,0.015,0.01$, and 0.007 , respectively). In group 1 , significant relationship was documented for age group $(P=0.005)$ and triple-negative cases $(P=$ $0.044)$, and marginally significant relationship for the number of metastatic sites $(P=0.051)$. However, in group 2, significant relationship was noted for the line of treatment and number of metastatic sites $(P=0.0 .39$ and $P=0.011$, respectively), as shown in Table 5 .
The mean TTP for all patients was $8.73 \pm 0.535$ months (95\% Cl: 7.68-9.77). In group 1, the mean was $8.16 \pm 0.63$ months $(95 \% \mathrm{Cl}: 6.91-9.41)$ and the median was 10.1 months, while the mean was $8.98 \pm 0.75$ months (95\% Cl: $7.50-11.45)$ with a median of 10 months in group 2 , without any statistically significant difference noted between them $(P=0.66$; Figure 1$)$. The OS had a mean of $11.95 \pm 0.546$ months in all patients, with a mean of 11.94 \pm 0.754 months $(95 \% \mathrm{Cl}: 10.46-13.42)$ and a median of 13.1 months versus a mean of $11.24 \pm 0.665$ months $(95 \%$ Cl: 9.94-12.54) with a median of 13 months in groups 1 and 2 , respectively. $(P=0.9$; Figure 2$)$.

\section{Discussion}

Capecitabine is a prodrug of 5-FU that is activated to 5-FU preferentially in tumor tissues due to increased expression of thymidine phosphorylase, which contributes to the drug's specificity against tumor cell proliferation $^{[12]}$. The FDA has approved capecitabine monotherapy in a dose of $1250 \mathrm{mg} / \mathrm{m}^{2}$ BID on days 1-14 followed by 7 days of rest for MBC that is resistant to both paclitaxel and anthracyclines ${ }^{[13]}$. However, clinical experience with this drug regimen indicated significant gastrointestinal toxicity as well as wide interpatient pharmacokinetic variability ${ }^{[14]}$. 


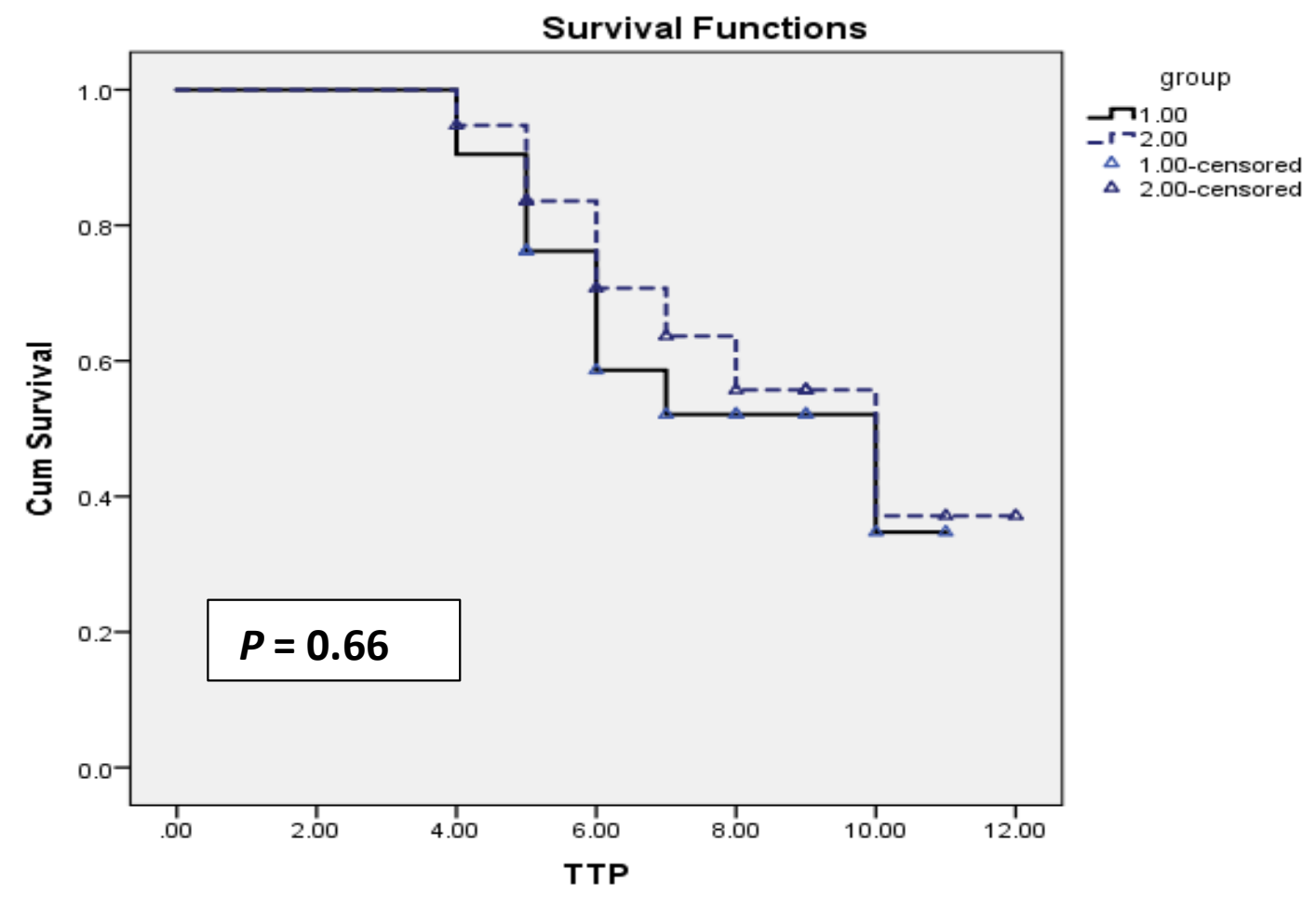

Figure 1: Time to progression in both groups.

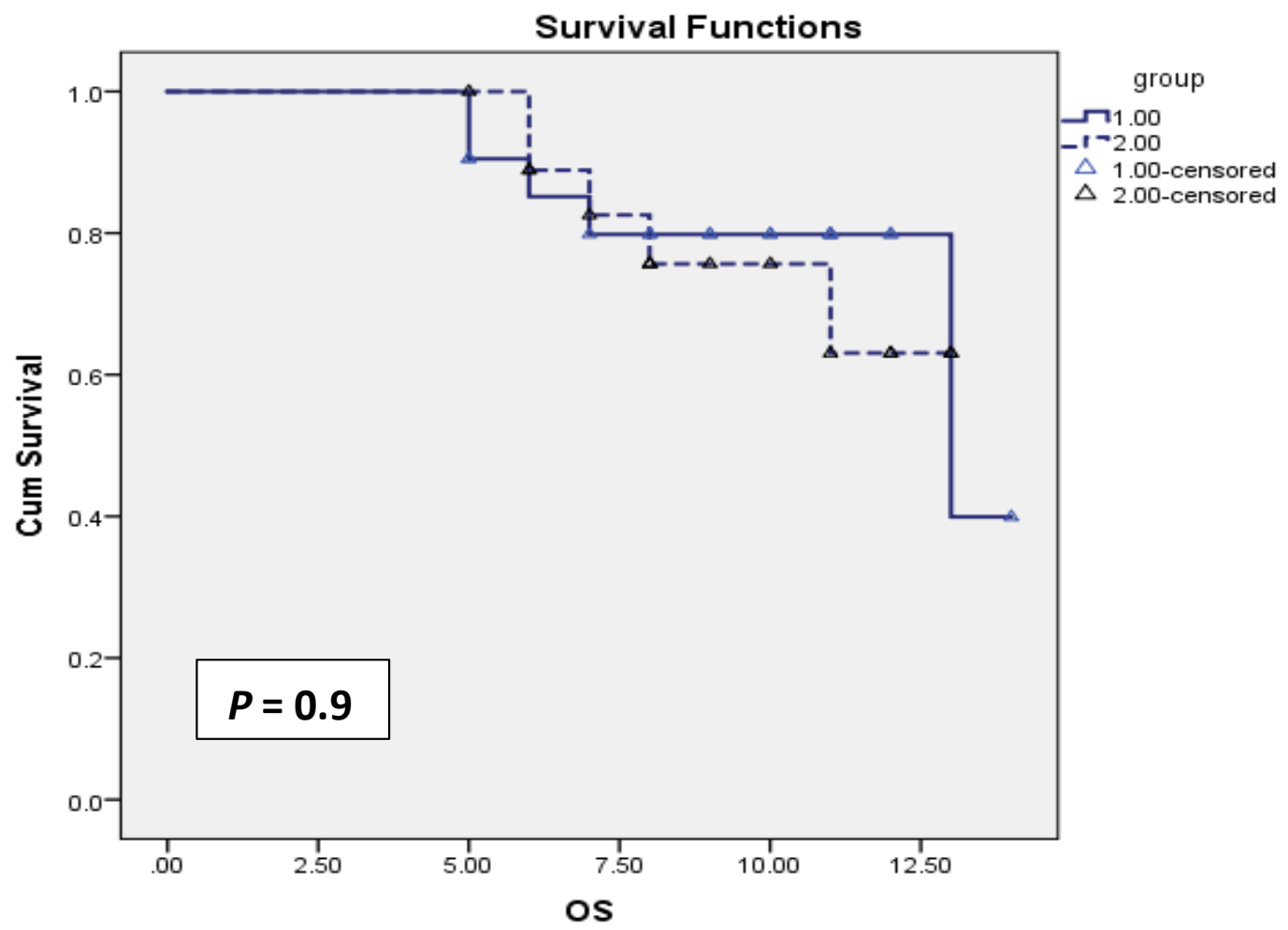

Figure 2: Overall survival in both groups 
Interestingly, Koedoot et al. reported that patients' age, wishes, and expected survival from treatment are factors that influence the decision of therapy ${ }^{[15]}$, which has led to the clinical use of lower doses of capecitabine ${ }^{[16,17]}$. Hence, we performed our prospective study to determine whether a lower dose of capecitabine ( $850 \mathrm{mg} / \mathrm{m}^{2}$ BID daily for 14 days every 3 weeks) can improve tolerability without compromising efficacy that is reported with a higher dose. In our study, patients treated with lower dose of capecitabine required dose reduction for the reported toxicity significantly less frequently than those treated with $1250 \mathrm{mg} / \mathrm{m}^{2} \mathrm{BID}(P=0.0005)$. The incidence of dose reduction with the lower and approved dose was $5.3 \%$ and $57.1 \%$, respectively. This finding matches the results of a meta-analysis conducted by Nishijima et al. ${ }^{[13]}$, which showed significantly lower dose reduction $(15.9 \%$ vs $39 \%, P=0.007)$ using a dose of $1000 \mathrm{mg} / \mathrm{m}^{2}$ versus $1250 \mathrm{mg} / \mathrm{m}^{2}$ BID for 14 days every 21 days $^{[13]}$.

Concerning the number of cycles, the median was six cycles in group 1. This result was consistent with that previously reported ${ }^{[18-20]}$. However, the median number of cycles in group 2 was eight cycles. This result was in agreement with other series ${ }^{[16,21]}$, but the difference was not statistically significant $(P=0.76)$. In the present study, two patients in group $1(9.52 \%)$ and one case in group $2(5.26 \%)$ discontinued treatment due to fatigue and gastrointestinal toxicities. Similarly, an insignificant difference in the incidence of treatment discontinuation between the two groups (1000 vs 1250 $\mathrm{mg} / \mathrm{m}^{2}$ of capecitabine) has been also recorded in another report ${ }^{[13]}$.

The incidence of severe toxicities in our study was low, with no observed adverse events greater than grade 3 . The most common adverse events included HFS, fatigue, diarrhea, and hematological toxicities, which were generally mild to moderate in intensity. The main side effect associated with capecitabine was HFS (all grades), which developed in $61.9 \%$ and $47.3 \%$ of patients in group 1 and group 2, respectively, but the difference was not statistically significant. This may be attributed to the small number of patients involved in our study. However, this is in accordance with the results of Hennessy et al. ${ }^{[22]}$. In addition, a previous study reported high grade of toxicity in $20 \%$ of patients receiving a dose of $1000 \mathrm{mg} / \mathrm{m}^{2}$. We did not detect highgrade HFS in group 2; this may be attributed to the low dose of capecitabine in our study. We recorded grade 3 diarrhea only in patients treated with standard dose of capecitabine $(14.2 \%)$ and this is consistent with the results of others ${ }^{[6,9,23]}$. Grade 3 neutropenia developed in one case treated with the approved dose (4.7\%); this agrees with other reports ${ }^{[22]}$.
Improved tolerability was documented in our study with the lower dose and appeared to be achieved without compromising efficacy. The overall clinical response was $38 \%$ versus $36.8 \%$ in group 1 and group 2 , respectively. This is consistent with the results of others ${ }^{[8,24]}$. On the other hand, other studies reported a lower overall clinical response in comparison to ours ${ }^{[6,22]}$. These data disagree with our series perhaps because patients were heavily treated with chemotherapy prior to capecitabine. Moreover, the rates of SD were $14.2 \%$ and $21 \%$ in group 1 and group 2, respectively, with a median disease stabilization of 25 and 28 weeks in group 1 and group 2, respectively, without statistically significant difference. Similar results were reported by Hennessy's et al.'s study ${ }^{[22]}$, which highlighted no greater benefit in response rate or disease stabilization with the approved dose than with a lower doses of capecitabine.

In our study, disease progression was recorded in $47.6 \%$ versus $42.1 \%$ of patients in groups 1 and 2 , respectively. However, the difference was statistically insignificant. These findings match the results of previous studies ${ }^{[7,8,25,26]}$. We found that the age, tumor grade, number of metastatic sites, and the line of treatment were independent prognostic factors for the overall clinical response in all patients. Similar results were shown in other reports ${ }^{[7,12]}$. On the other hand, Zielinski et al. documented in their univariate analysis no significant influence of prior adjuvant chemotherapy, or endocrine therapy, visceral disease, or initial capecitabine dose on the efficacy of treatment ${ }^{[24]}$. This difference may be attributed to the different patient populations studied, as well as the different number of patients included in the studies.

Many studies had noticed that the median TTP with a lower starting dose of capecitabine was similar to that with the approved dose of capecitabine in $\mathrm{MBC}^{[27-29]}$. Similar results were reported by Debled et al. ${ }^{[30]}$ who found that there was no difference in time to treatment failure according to capecitabine starting dose. These results reinforce our report which showed that the mean TTP was $8.16 \pm 0.63$ months (median 10.1 months) versus $8.98 \pm 0.75$ months (median 10 months) in groups 1 and 2, respectively, without statistically significant difference. As regards the OS, there was no statistically significant difference between both groups (mean of $11.94 \pm 0.754$ months and median of 13.1 months vs mean of $11.24 \pm 0.655$ months and median of 13 months in groups 1 and 2, respectively). This is consistent with the results of previous analyses ${ }^{[24,29,31]}$, which elucidated that a lower starting dose of capecitabine improved tolerability without compromising efficacy. A limitation of our study is the relatively small number of patients, which may preclude detection of very small differences. 


\section{Conclusion}

Capecitabine remains an important therapeutic strategy in $\mathrm{MBC}$ due to its oral formulation and ease of dose modifications. A lower incidence of dose reduction and of high-grade HFS, diarrhea, and neutropenia was observed in capecitabine given at a dose of $850 \mathrm{mg} /$ $\mathrm{m}^{2}$ BID compared to $1250 \mathrm{mg} / \mathrm{m}^{2}$ BID. Therefore, our findings reveal that a lower dose of capecitabine (850 $\mathrm{mg} / \mathrm{m}^{2}$ BID) provides patients with an active therapy to be continued for prolonged periods to achieve long-term disease control without compromising antitumor activity.

\section{Acknowledgment}

We are grateful to all colleagues for their help and advice that were granted to us.

\section{Compliance with ethical standards}

The authors declare that they have no conflict of interest.

All procedures performed in study were in accordance with the ethical standards of our institution and in accordance with the ethical standard of Deceleration of Helsinki 1964. Informed consent was obtained from all patients before they participated in the study.

\section{References}

[1] Diasio RB. An evolving role for oral fluoropyrimidine drugs. J Clin Oncol 2002; 20: 894-896.

[2] Schuller J, Cassidy J, Dumont E, et al. Preferential activation of capecitabine in tumor following oral administration in colorectal cancer patients. Cancer Chemother Pharmacol 2000; 45: 291-297.

[3] Miwa M, Ura M, Nishida M, et al. Design of a novel oral fluoropyrimidine carbamate, capecitabine, which generates 5-fluorouracil selectively in tumours by enzymes concentrated in human liver and cancer tissue. Eur J Cancer 1998; 34: 1274-1281.

[4] Twelves C. Vision of the future: Capecitabine. Oncologist 2001; 6 (Suppl 4): 35-39.

[5] Cassidy J, Twelves C, Van Cutsem E, et al. First-line oral capecitabine therapy in metastatic colorectal cancer: A favorable safety profile compared with intravenous 5-fluorouracil/leucovorin. Ann Oncol 2002; 13: 566-575.

[6] Fumoleau P, Largillier R, Trillet-Lenoir V, et al. Capecitabine (Xeloda) in patients with advanced breast cancer $(A B C)$, previously treated with anthracyclines and taxanes: a large Phase II study. Proc Am Soc Clin Oncol 2002; 21:62

[7] O'Shaughnessy J, Blum J, Moiseyenko V, et al. Randomized, open label, phase II trial of oral capecitabine (Xeloda) vs. a reference arm of intravenous CMF (cyclophosphamide, methotrexate and 5-fluorouracil) as first-line therapy for advanced/metastatic breast cancer. Ann Oncol 2001; 12: 1247-1254.

[8] O'Shaughnessy J, Miles D, Vukelja S, et al. Superior survival with capecitabine plus docetaxel combination therapy in anthracycline pretreated patients with advanced breast cancer: Phase III trial results. J Clin Oncol 2002; 20: 2812-2823.

[9] Blum JL, Dieras V, Lo Russo PM et al. Multicenter, phase II study of capecitabine in taxane-pretreated metastatic breast carcinoma patients. Cancer 2001; 92: 1759-1768.

[10] Taguchi T, Nakayama T, Masuda N, Yoshidome K, et al. Study of low-dose capecitabine monotherapy for metastatic breast cancer. Chemotherapy 2010; 56(2):166-170.

[11] Ambros T, Zeichner SB, Zaravinos J, Montero AJ, Ahn E, Aruna $M$, et al. A retrospective study evaluating a fixed low dose capecitabine monotherapy in women with HER-2 negative metastatic breast cancer. Breast Cancer Res Treat 2014;146(1):7-14.

[12] Bertelsen C, Ji L, Garcia A, Russell C, et al. Efficacy of Very-Low-Dose Capecitabine in Metastatic breast Cancer . Am J Hematol 2014; 11(2):20-30

[13] Nishijima T, Suzuki M, Hyman B. A comparison of toxicity profiles between the lower and standard dose capecitabine in breast cancer: a systematic review and meta-analysis. Breast Cancer Res Treat 2016 April ; 156(2): 227-236.

[14] Rudek M, Connolly R, Hoskins J, Mayer E, et al. Fixed dose capecitabine is feasible: results from a pharmacokinetic and pharmacogenetic study in metastatic breast cancer .Breast Cancer Res Treat 2013 May ; 139(1): 135-143.

[15] Koedoot CG, De Haes JC, Heisterkamp SH, Bakker PJ, et al. Palliative chemotherapy or watchful waiting? A vignettes study among oncologists. J Clin Oncol 2002;20(17):3658-3664. 
[16] Rossi D, Alessandroni P, Catalano V et al. Safety profile and activity of lower capecitabine dose in patients with metastatic breast cancer. Clin Breast Cancer 2007; 7(11): 857-860.

[17] Kawaguchi $\mathrm{T}$, Iwase $\mathrm{S}$, Takeuchi $\mathrm{H}$, et al. Chemotherapy with low-dose capecitabine as palliative treatment in a patient with metastatic breast cancer: a case report. Cases J 2009;2:9081.

[18] Blum JL, Jones SE, Buzdar AU, et al. Multicenter phase II study of capecitabine in paclitaxelrefractory metastatic breast cancer. J Clin Oncol 1999; 17(2): 485-493.

[19] Van Cutsem E, Findlay M, Osterwalder B, et al. Capecitabine, an oral fluoropyrimidine carbamate with substantial activity in advanced colorectal cancer: results of a randomized phase II study. J Clin Oncol 2000; 18(6): 1337-1345.

[20] Haller DG, Cassidy J, Clarke SJ, et al. Potential regional differences for the tolerability profiles of fluoropyrimidines. J Clin Oncol 2008; 26(13): 21182123.

[21] Sezgin C, Kurt E, Evrensel T et al. Efficacy of lower dose capecitabine in patients with metastatic breast cancer and factors influencing therapeutic response and outcome. South Med J 2007; 100(1): 27-32.

[22] Hennessy B, Gauthier A, Michaud L, Hortobagyi $\mathrm{G}$, et al Lower dose capecitabine has a more favorable therapeutic index in metastatic breast cancer: retrospective analysis of patients treated at M. D. Anderson Cancer Center and a review of capecitabine toxicity in the literature. Ann Oncol 2005; 16: 1289-1296.

[23] Cassidy J, Twelves C, Van Cutsem E, et al. First-line oral capecitabine therapy in metastatic colorectal cancer: A favorable safety profile compared with intravenous 5-fluorouracil/leucovorin. Ann Oncol 2002; 13: 566-575.

[24] Zielinski C, Gralow J, Martin M. Optimizing the dose of capecitabine in metastatic breast cancer: confused, clarified or confirmed? Ann Oncol 2010; 21: 2145-2152.

[25] Hoff PM, Ansari R, Batist G, et al. Comparison of oral capecitabine (Xeloda) $v$ intravenous 5-fluorouracil plus leucovorin (Mayo Clinic regimen) as first-line treatment in 605 patients with metastatic colorectal cancer: Results of a randomized phase III study. J Clin Oncol 2001; 19: 2282-2292.
[26] Talbot DC, Moiseyenko V, Van Belle S, et al. Randomised, phase II trial comparing oral capecitabine (Xeloda) with paclitaxel in patients with metastatic/advanced breast cancer pretreated with anthracyclines. Br J Cancer 2002; 86: 13671372.

[27] Harbeck N, Saupe S, Jäger E, Schmidt M, et al. A randomized phase III study evaluating pegylated liposomal doxorubicin versus capecitabine as firstline therapy for metastatic breast cancer: Results of the PELICAN study. Breast Cancer Res Treat 2017;161(1):63-72.

[28] Robert NJ, Dieras V, Glaspy J, Brufsky AM, Bondarenko I, Lipatov ON, et al. RIBBON-1: randomized, double-blind, placebo-controlled, phase III trial of chemotherapy with or without bevacizumab for first-line treatment of human epidermal growth factor receptor 2-negative, locally recurrent or metastatic breast cancer. J Clin Oncol 2011; 29(10):1252-1260.

[29] Stockler MR, Harvey VJ, Francis PA, Byrne MJ, Ackland SP, Fitzharris B, et al. Capecitabine versus classical cyclophosphamide, methotrexate, and fluorouracil as first-line chemotherapy for advanced breast cancer. J Clin Oncol 2011; 29(34):44984504.

[30] Debled M, Madranges N, Trainaud A, et al. First-line capecitabine monotherapy for slowly progressing metastatic breast cancer: do we need aggressive treatment? Oncology 2009; 77: 318-327.

[31] Bajetta E, Procopio G, Celio L, et al. Safety and efficacy of two different doses of capecitabine in the treatment of advanced breast cancer in older women. J Clin Oncol 2005; 23(10): 2155-2161. 